\title{
Introduction to Pragmatism and Idealism
}

Paul Giladi and Aaron B. Wilson

\section{(2) OpenEdition}

\section{Journals}

Electronic version

URL: http://journals.openedition.org/ejpap/1289

DOI: 10.4000/ejpap.1289

ISSN: 2036-4091

\section{Publisher}

Associazione Pragma

\section{Electronic reference}

Paul Giladi and Aaron B. Wilson, «Introduction to Pragmatism and Idealism », European Journal of Pragmatism and American Philosophy [Online], X-2 | 2018, Online since 11 January 2019, connection on 23 September 2020. URL : http://journals.openedition.org/ejpap/1289 ; DOI : https://doi.org/10.4000/ ejpap.1289

This text was automatically generated on 23 September 2020 .

\section{c)}

Author retains copyright and grants the European Journal of Pragmatism and American Philosophy right of first publication with the work simultaneously licensed under a Creative Commons AttributionNonCommercial-NoDerivatives 4.0 International License. 


\title{
Introduction to Pragmatism and Idealism
}

\author{
Paul Giladi and Aaron B. Wilson
}

\section{Introduction}

1 Recent years have seen increased interest in the complex relationships between the thought of German Idealists (understood to include both transcendental and absolute idealists) and the thought of those philosophers commonly categorized as "American Pragmatists" - from Charles S. Peirce (the progenitor of this alleged tradition) to Richard Rorty and his student, Robert Brandom. This issue presents a collection of papers that, as a collection, do justice to those complex relationships, neither pretending that idealism and pragmatism are natural allies, nor pretending that they are, essentially, rivals. Readers who seek critical perspectives on these relationships will find this issue has much to offer. However, there is also no shortage of insights on the agreements or points of convergence between idealism and pragmatism. This mixed approach to their relationships, even if it is ultimately more critical than it is positive, reflects the very attitudes of many pragmatist authors toward the thought of German Idealists, from Peirce's and Dewey's own mixed evaluations of Kant and Hegel, to Lewis's rejection of the transcendental a priori in favor of the "pragmatic a priori," to figures such as Royce, who sees his work as both Hegelian and pragmatist. Inasmuch as pragmatist authors themselves comprise an extended and querulous family, so in relating them to the German Idealists, we only extend that querulous family even further.

2 We begin with Willem deVries's "From Idealism to Pragmatism: a Matter of Evolution." Distinguishing between two modern types of idealism, one motivated by epistemological concerns and traceable to Descartes, and the other motivated directly by metaphysical concerns and characteristic of Hegel, deVries argues that pragmatism is distinct from idealism, as pragmatists are motivated most directly by a concern for practice, such as (in Peirce) the practice of inquiry. But while pragmatism never falls 
back into idealism, it has in common with idealism "the priority of system." Next is Vincent Colapietro's "Actuality and Intelligibility," which turns to Peirce's famous criticism of Hegel, that, in his system, Hegel fails to give proper priority to the role of "Secondness" or "active oppugnancy" in experience, making "Thirdness" or reason the primary metaphysical principle. Colapietro argues that, to the contrary, a deeper look at the role of conflict in Hegel's system shows not only that this criticism is unfair, but also, Hegel and Peirce aside, how akin experience and reason actually are. Continuing with Peirce, Aaron B. Wilson contends that, while Peirce's philosophy is not consistent with idealism insofar as the latter assumes we can have a priori knowledge, Peirce's "hypothesis of the Final Opinion" can be viewed as a "transcendental feature" of his system, as it explains how knowledge in general is possible; moreover, it does so in a way that resembles the "Absolute" of absolute idealism. However, the hypothesis of the Final Opinion is not epistemically independent of experience, since the hypothesis is an abduction from experience.

3 Turning to other members of the pragmatist family, in "Reclaiming the Power of Thought," Jörg Volbers examines Dewey's own ambivalent attitude toward idealism. Dewey at once defends idealism as an historical improvement over authority-based systems, and criticizes it for subordinating practical activity to intellectual activity. For Dewey, both forms of activity form a dynamic, temporal whole, which is key to understanding experience and rationality. In "Voluntarism: A Difference that Makes the Difference between German Idealism and American Pragmatism?," Daniel Brunson examines how Royce's voluntarism, which treats will as more fundamental (metaphysically) than intellect, offers a way of distinguishing between idealism and pragmatism. Providing rich historical detail, Brunson surveys the thought of and exchanges between Royce, Peirce, Dewey, Schiller and others to suggest how any contest between idealism and pragmatism could be recast as one between intellectualism and voluntarism. The influence of the early pragmatists notwithstanding, Terry Pinkard's "Conceptualistic Pragmatism" contends that the thought of C. I. Lewis was the dominate formative influence in the development of postwar pragmatism, providing the framework for Quine, Sellars, Rorty and Brandom. Further, although there are important differences between Lewis and the post-Kantian idealists, Lewis engages the very debates the German idealists had among themselves, thereby passing those debates onto the post-war pragmatists. Finally, in "Hegel and the Ethics of Brandom's Metaphysics," Jonathan Lewis examines Brandom's appropriation of key themes in German Idealism, particularly the normativity of meaning, and argues that, unlike Hegel, Brandom fails to respect the ethical dimensions of this normativity. Brandom mistakenly divorces ethical concerns from meaning normativity; but Lewis suggests that a Hegelian solution to this inadequacy in Brandom would undercut a key assumption of his inferential semantics. 


\section{AUTHORS}

PAUL GILADI

Manchester Metropolitan University

p.giladi[at]mmu.ac.uk

AARON B. WILSON

South Texas College

awilson3[at]southtexascollege.edu 